\title{
Will minority languages survive in the information society? An Israeli point of view
}

\section{CHAIM SEYMOUR}

\author{
Department of Information Studies and Librarianship, Bar-Ilan
}

University, Israel.

\begin{abstract}
School of Information Management, University of Brighton,
\end{abstract} United Kingdom.

\begin{abstract}
The article raises the role of the minority national language within a global infomation society. The Hebrew language is a unique case of the revival of a classic language. In the early twentieth century a project was carried out to establish a technical university in what was then called Palestine The founders preferred to teach in Cerman, the dominant intemational scientific language technology. They clained that Hebrew was unsuitable for scientific discourse. The opposition succeeded in defeating the founders and thus guaranteed the use of Hebrew in the fields of science and technology. The changing relationships and tension between the local language and the intemational lingua franca is still subject to debate today and the events of the so-called language war have much to teach us.
\end{abstract}

\section{Introduction}

This year marks the 50th anniversary of Israel's independence. The declaration of Independence in 1948 was preceded by many years of preparation. Many of the discussions which preceded the establishment of the State of Israel, continue today and many of the decisions and issues which have been resolved have influenced practices in schools today, creating frameworks for teachers and school librarians.

In 1981, Esther Dyer presented a paper to this conference (The International Association of School Librarianship). It was entitled "Bilingualism and School Library Development: USA" and dealt with services to Spanish speaking pupils in the United States. The paper opens with a timely reminder: "Librarianship and ethnicity are inescapably intertwined. In the broadest sense, the function of libraries, be they public, school or academic institutions, is to serve their communities." (Dyer, 1989, p.107).

A recurring theme or motif in the Biblical book of Ecclesiastes is that there is nothing new under the sun. In order to understand Israel's present situation, it will be necessary to consider a period of approximately 100 years commencing in the 1880 s. Especial attention will be paid to the period between approximately 1910 and 1924. The issues addressed are still being considered today and have considerable relevance both to the nature of the 
relationship between the individual nation and the 'global information society' and to the decisions which have been taken and will be taken on the way to European Union. Europe today essentially works on three levels, at the lowest level the ethnic unit, above that the Nation State which is not necessarily identical with the ethnic unit and on the highest level the European ruling body. The place of the ethnic (often minority) language both in society in general and in the school curriculum in particular is a major issue.

One of the first questions that arises in any multilingual and/or multicultural society is: what is the appropriate language of instruction in the schools? Is there a common language? Should the language be a local language or is an international lingua franca preferable? The answer to this question has ramifications beyond the educational aspects. It is not only a cultural question but also a political question. In India, for example, the attempt to introduce Hindi as the national language sparked unrest, the government was forced to retract and English remained the common language. In the case of Israel, Hebrew is an integral part of the Israeli national renaissance.

This session considers the question of minority languages. A minority language can be either the language of a minority within a country such as French in Canada or a minority national language within the global society such as Hebrew

Our approach to the question of minority languages in the global information society is dictated by our conception of the 'global information society'? The age in which we live has variously been described as "the post-industrial age" or as "the information age." There are two schools of thought regarding the transition from the "industrial age" to the "information age." Toffler (1981) represents the thinkers who see the change as revolutionary. Giddens (1993, p. 284) discusses what he calls 'a set of discontinuities associated with the modern period." The other school represented by Webster (1995) and Martin (1995) both see the changes as evolutionary. We would adopt the latter view that there is a continuity between the industrial society and its successor, the 'global information society'.

Does the average individual, wherever he lives, see the same soap operas and news broadcasts? The answer, in most cases, is yes. The next question is how do these programs affect him? It would be hard to give a scientific answer, but one can certainly assume that American (Western) values and not necessarily their most positive values penetrate through the back door. The effect of the information Society has been to open up the world, forming what McLuhan (1989) called a 'global village'. In this global village, there are big, influential citizens and small less influential citizens. How do the less influential citizens want to live their lives?

Laver (1996, p.21) points out that there are some 50 million concepts and terms within 200 different sections of contemporary scientific, technical and commercial vocabulary. His implicit assumption is that it is doubtiul if all languages are capable of providing the full range of terminology necessary within the modern world.

If one consciously limits the range of a given minority language, or does not attempt to extend its range beyond a given point what is required of a language for it to survive and remain viable? 
What today is a minority language? The question is no longer clear-cut. French, which is certainly one of the world's major languages; feels so threatened by English that in 1994, the loi Toubon was promulgated to defend France's national language.

\section{The case of Hebrew}

Israel's language, Hebrew is one of the world's oldest living languages, if not the oldest, yet one of the latest modern languages to appear on the world's stage.

Parkes (1970, p.227) quotes a British consular report submitted in 1839 which estimated the Jewish population in what was then called Palestine to be about 10,000 , whereas the estimate for 1888 (p.230) was 45,000.

Up until the 1880s, the Jewish population in Palestine was composed mainly of Rabbinical students and their families living on the charity of their brethren However, in 1870, the first agricultural school was established in Mikveh Yisrael. In 1875, a new settlement Petach Tikvah was founded. It was the first Jewish settlement which was intended to be self-supporting, basing itself on agriculture. The 1880s saw the establishment of an additional 4 settlements, Zikron Yaakov, Rosh Pina, Rishon le-Zion with an additional settlement north of Rosh Pina.

Prior to 1880 , Hebrew was read and written but rarely spoken. By 1922, the British Mandatory authorities in Palestine regarded it as natural to designate Hebrew as one of the three official languages within the Mandate which they assumed for Palestine.

Attempts to revive the national language have been made in Scotland, Wales and Ireland, for example, with less success and in Norway perhaps more successfully. Glinert (1993), however, considers it "... a language movement that has no parallel in history; the successful conversion of a written classical language into a de novo mother tongue." (p.85).

Eliezer Ben-Yehuda, who was to be one of the key figures behind the renaissance of the Hebrew language emigrated to Palestine and settled in Jerusalem in 1881 (Fellman, 1979, p.27). At that time, the Jews were a majority in Jerusalem, numbering some $54 \%$ of the population. However, they were composed of many small communities originating from different countries and speaking different languages. The chief languages spoken were Yiddish (Judeo-German), Ladino (Judeo-Spanish) and Arabic. Hebrew, spoken using the 'Sephardic' pronunciation, was the only common language among the Jews (Fellman, 1979, p.27-29).

Ben-Yehuda aimed to influence the linguistic behavior of the lews and began by establishing his family as the first Hebrew-speaking household. His example was followed by four additionall families (Fellman, 1979, p.37).

His other activities included the establishment of a Hebrew speaking society, the starting of a newspaper in Hebrew and the preparation of a dictionary.

The attempts to influence behaviors of people (Cooper, 1989) were most fruitful with in the educational system. The teachers could be regarded as the main 'implementers' of the language policy. Nissim Bechar was the principal of the Torah U-Melakha School, which had been established by a Jewish French charitable organization, Alliance Israelite Universelle. In 1883, he offered Ben-Yehuda the opportunity to teach Hebrew language 
classes in the school. Ben-Yehuda was a pioneer of teaching Hebrew in Hebrew. He resigned after only a few months, due to ill health. However, he showed the way for David Yellin and Joseph Meyuhas, who adopted his methods. His methods spread to the new agricultural settlements outside Jerusalem (Fellman, 1979, p.49-55).

Teaching in Hebrew commenced in Jerusalem, but continued in the agricultural settlements. There the schools were of two types. The first type, used traditional methods, teaching in Yiddish. However, other schools established by pioneering students from Eastern Europe in places such as Eqron and Gedera, taught in Hebrew using Ben-Yehuda's methods and textbooks were prepared in history, geography, arithmetic, reading, grammar, etc. (Fellman, 1979, p.95).

The first Teachers' Association was founded in 1892 with 19 members. This association fixed the minimum age of students, curriculum and teaching methods (Fellman, 1979, p.97). The Teachers' association was involved in the preparation of textbooks, which at that time was very much more difficult than today. The language still lacked terms for basic concepts. Thus, for example, the word for a 'pen' 'et' occurs in the Bible, but what is a fountain pen? It becomes 'et novea', literally 'a flowing pen'. Similarly 'iparon', a 'pencil' was derived from the Hebrew word for 'lead' and the word for 'exercise book' taken from the word 'to join'. There was no doubt at all about the need to coin words, what concerned the teachers was how to ensure that a given term would have national provenance and that teachers in the South, for example, would not develop a different language from those in the North.

A Language Council was first set up in 1890 and afterwards disbanded in 1891, to be reconvened in 1904. The role of the Council in the development of the language was relatively minor at the beginning of its existence. However from 1917, it assumed a more central role and the position of The Hebrew Language Academy today is defined by legislation and far stronger than that of the parallel Academie francaise.

Over the years, the aims of the Council have not really changed. Ben-Yehuda emphasized four functions which are: to record all Hebrew terms from the corpus of written Hebrew, to create new words based on existing roots or cognates from other, preferably, Semitic languages, to standardize pronunciation and spelling (Fellman, 1973, p.82).

The continuity of the process is underlined by the fact that today one can access the Academy's home page and you will be invited to submit your suggestion for a Hebrew term for 'milk shake'.

"In 1913, there were throughout the country, sixty-six all-Hebrew institutions, serving some 2600 students: 20 Hebrew kindergartens ... 28 elementary Hebrew schools on the colonies and six in the cities ... one women teachers' seminary ... one kindergarten teachers' institute ... two commercial schools ... an artists' school ... an agricultural school" (Fellman, 1979, p.104-105).

Wahl (1996) discusses the role of German in 19th century and early 20th century Palestine. Up until the end of the First World War, Palestine was under Turkish rule. The foreign consuls, especially the German and Austrian consuls worked hard to establish a sphere of influence. Since the Ottoman ruler was not always so enlightened, foreign citizenship could be very useful for the Jew and he could take advantage of the fact that the German and Austrian consulates in Jerusalem were active in propagating Cerman 
culture among the Jewish population and that there was competition between the Cerman and French consulates to extend their spheres of influence. Later, there was an alliance between the German and British Protestants against the French Catholics.

In 1901 Dr. Paul Nathan and James Simon established the Hilfsverein der deutschen Juden which in turn promoted a network of schools in Palestine in which the primary language of instruction was German. Hebrew was also taught in their schools.

\section{The Technion}

1911 saw the preparations for a technical university in Haifa. It was to be based on a German model, including a secondary school to prepare its future pupils. The language of instruction was supposed to be German. The foundation stone was set in 1912. There was growing friction between the pro-German language founders and the Zionists, who realized that the language of instruction in the Technion would determine the future or lack of future of Hebrew as a modern language. The years 1913-1923 witnessed the so-called "Sprachenkrieg" (language war) (Sadmon, 1994, p. 3)

The meeting of the Kuratorium, the body established to direct the Technion, which was supposed to determine the language of instruction in the Technion was convened (without its American members) on the 26th. October, 1913 (Sadmon, p.170).

Shmarya Levin, a Zionist leader, summarized the case for Hebrew:

1. It was the national language and part of Israel's rebirth.

2. It would protect the Jewish nature of the Technion.

3. Hebrew was politically neutral and not identified with any of the Great Powers.

4. The use of German would antagonize Jewish militants.

"Paul Nathan ... insisted that the language controversy was a matter of principle and failure to endorse his stand would be regarded by him as a vote of non-confidence. He and his German associates would resign" (Alpert, 1982, p.43).

Levin's proposal was defeated 16:3, The Kuratorium decided:

1. To take no decision regarding the official language.

2. To allocate a prominent place for Hebrew.

3. Arabic and Turkish to be emphasized.

4. Science and technology to be taught in German.

5. English and French to be taught.

The three Zionist members of the Kuratorium resigned.

A typical reaction of the Zionist press: "Ohne eigene Sprache hingen alle Kulturbestrebungen in Palaestina voellig in der Luft" (Sadmon, p.173). The debate sounds familiar to our ears. On the one side, we find those that claim that science and technology should be taught in the international lingua franca for science and that the local language is not sufficiently developed to meet the needs of scientific discourse. The opposition admit that Hebrew, the local language may not be sufficiently developed for scientific discourse, but claim that the answer is to develop the language to meet the needs of its speakers, 
otherwise Hebrew would have no future as a spoken language. At this stage in history, a small group of intellectuals, mainly teachers determined the future of the Hebrew language and initiated the current debate on the role of a minority language in a global society. Hebrew received the strong support which is lacking in the case of the various Gaelic languages for instance.

November, 1913 witnessed a demonstration against the Hilfsverein, led by Dr. Auerbach in Haifa. The Teachers' Seminar in Jerusalem struck and Nathan suspended the teachers. The teachers' organization started a country wide boycott of the Hilfsverein educational system.

The Zionists exerted pressure on the American directors of the Technion. In February 1914 , the Zionists succeeded in passing a motion in the board of directors, that in the Grammar school attached to the Technikum the language of instruction would be Hebrew. As for the Technion itself, there would be a four year transitional period from Cerman to Hebrew. The opposition fought back by declaring the Technion bankrupt.

A result of the 'language war' was the replacement of the Hilfsverein educational system by a Zionist system. "Six new institutions were opened at once in Jerusalem, Haifa and Jaffa, where all subjects were taught in Hebrew. Of the 56 Hilfsverein teachers, 41 unhesitatingly went over to the new schools. Of the 1115 pupils, more than half made the switch at once. By the end of the war [1918] there were 27 Zionist schools" (Alpert, 1982, p.61).

The Zionist organization bought the Technion in 1920. Teaching commenced in December 1924. The language of instruction was Hebrew, and the syllabus was German.

Until recently, Israel's Language Academy had an office within the Technion which was responsible for the development of technical vocabulary. The weekend magazine of the Israeli daily Ha-Aretz in its issue for 1.8.97 included an interview with Prof. Shraga Irmai, of the Technion. He explained the Hebrew Academy's policy. Priority is given to coining words for teaching at school and university level. The more esoteric subjects, such as astrophysics for example, are avoided.

\section{Conclusions}

Charlotte Hoffmann (1996) in her collection, Language Culture and Communication in Contemporary Europe is concerned with the role of smaller countries in a United Europe. It is clear, that a global society using one language will be far more efficient than the present European Union with its multitude of official languages. However, if information is provided in only one language, only the elite who know the language will have access to new information. As she says in her introduction: "such a decision would carry with it the risk of creating a two-tier society as those without knowledge of that language would be denied access to new forms of communication and information" (p.x-xi)

Laver (1996) in the keynote address to the Hoffman collection sees the information revolution as a threat to linguistic diversity. The use of a single language not only penalizes the citizen who does not know the language, but also penalizes the citizen's language. He claims: "By reducing the range of usability of these (i.e. European) languages, their viability is threatened. And the viability of a language is inextricably linked to the health of the culture with which it is associated" (p.2). 
It is doubtful if all languages are capable of providing the full range of terminology necessary within the modern world. Recognition of this fact does not imply that languages should be abandoned. What it implies is the need to encourage 'diglossia', i.e. the use of two different languages for different purposes. This phenomenon is wide-spread within immigrant communities, where the mother tongue is used at home and the national language in the street and at school. In the same way, there would be a language for international communications and a language for national communications. The French Loi Toubon points out that language is an essential part of a nation's personality and patrimony and endows it with a privileged status in the fields of teaching, work and public services. The information society is creating a situation where national languages will no longer be able to function in the more specialist spheres. One would assume that there will be resistance to the process but that in the long run it is inevitable.

Schools and their libraries in countries like Israel, have to find a way to maximize the use of the local language in the Information society on one hand, but on the other hand, they must help their students who will have no alternative but to work with the international lingua franca, English.

In this discussion, we have attempted to examine a number of key questions relevant to contemporary society.

We would claim that just as the individual wants to express himself within his society, so each society wants to express itself with the global framework. The national language is a key part of the society's identity. However, just as the individual has to obey the laws of his society, so the nation has to function within a global framework. How does one resolve the tension between the two demands?

We would claim that, in the light of the continuity from the past, one should learn the lessons of the so called 'language war' in the early part of this century in order to address the cognate problems which face our contemporary society. There is a place for a minority national language and national identity but the nature of this identity has to be continually defined and redefined vis a vis the 'global information society'.

\section{References}

Alpert, C. (1982) Technion: the story of Israel's Institute of Technology. New York: American Technion Society.

Cooper, R.L, (1989). Language planning and social change. Cambridge: Cambridge University Press.

Dyer, E. (1989). Bilingualism and School Library Development: USA. In Hauck, P. (Ed.). Voices from around the world: Selections from the annual proceedings of the International Association of School Librarianship (pp. 106-118). Metuchen: The Scarecrow Press. 
Fellman, J. (1973). The revival of a classical tongue: Eliezer Ben Yehuda and the modern Hebrew language. The Hague: Mouton. Contributions to the Sociology of Language.

Giddens, A. (1993). The Giddens Reader, edited by P. Cassell. Basingstoke: MacMillan.

Glinert, L.H. (1993). The first conference for Hebrew, or when is a conference not a conference. In J.A. Fishman (Ed.), The earliest stage of language planning: The first congress phenomenon (pp. 85-115). Berlin: Mouton de Gruyter.

Hoffmann, C. (ed.) (1996). Language, culture and communication in contemporary Europe. Clevedon: Multilingual Matters.

Laver, J. and J. Roukens (1996). The global information society and Europe's linguistic and cultural heritage. In Hoffmann, C. (Ed.), Language, culture and communication in contemporary Europe (pp. 1-27). Clevedon: Multilingual matters.

Martin, W.J. (1995). The global information society. Aldershot: Aslib Gower.

McLuhan, M. and B.R. Powers (1989). The global village: Transformations in world life and media in the 21st Century. New York: Oxford University Press.

Parkes, J. (1970). Whose land? a history of the peoples of Palestine (revised edition). Harmondsworth: Penguin.

Sadmon, Z.W. (1994). Die Gründung des Technions in Haifa im Lichte deutscher Politik, 1907-1920. München: Saar. Einzelveröffentlichungen der Historischen Kommission zu Berlin, Bd. 78.

Toffler, A. (1981). The third wave. New York: Bantam.

Wahl, R. (1996). German language policy in 19th century Palestine. Ramat Gan. (Unpublished M.A. thesis, Bar-llan University).

Webster, F. (1995). Theories of the information society. London: Routledge. International Library of Sociology. 